\title{
O TRONCO HISTÓRICO DA DANÇA AFRO-BRASILEIRA
}

\author{
Marilza Oliveira da Silva ${ }^{1}$
}

Resumo: O histórico da dança negra no Brasil, especificamente na cidade de Salvador é marcado pela resistência dos seus disseminadores que reconhecem nela o reflexo da história e memória de um povo. Mesmo vista por muitos como uma dança marginal, exótica e ancorada na linha da invisibilidade, ainda sobrevive. Torna-se, portanto relevante abordar pungentes fatos colonizadores pelos quais o negro e sua cultura passaram a fim de desfazer distanciamentos de ordem histórica e social. Neste artigo apresento um histórico sobre o surgimento da dança afrobrasileira e as figuras marcadamente responsáveis por esse advento. O espaço Soteropolitano como o lugar onde os ramos do tronco se desdobraram tornaram-se um local de referência para as pesquisas voltadas para a dança afro, principalmente a inspirada na dança dos orixás.

Palavras-chave: dança afro-brasileira; história; ensino.

\section{THE HISTORICAL TRUNK OF AFROBRASILEIRA DANCE}

\begin{abstract}
The history of black dance in Brazil, specifically in the city of Salvador, is marked by the resistance of its disseminators, who recognize in this dance the reflection of the history and memory of black people. Despite being seen by many as a marginal dance, exotic and anchored in the line of invisibility, it still survives. It is therefore relevant to address relevant historical facts of colonization faced by the black and his culture, in order to undo historical and social silences. In this article I present a history about the emergence of Afro-Brazilian dance and the social actors markedly responsible for its development. The Soteropolitan space as the place where the branches of the trunk unfolded became a place of reference for the research focused on Afro dance, mainly inspired by the dance of the orixás.
\end{abstract}

Keywords: Afro-brazilian dance; history; teaching.

\section{LE COFFRE HISTORIQUE DE LA DANSE AFRO-BRÉSILIENNE}

Résumé: L'histoire de la danse noire au Brésil, en particulier dans la ville de Salvador, est marquée par la résistance de ses diffuseurs qui y reconnaissent le reflet de l'histoire et de la mémoire d'un peuple. Même vu par beaucoup de personnes comme une danse marginale, exotique et ancrée dans la ligne d'invisibilité, elle survit toujours. Il est donc pertinent de s'attaquer aux piquants faits de colonisation par lesquels les noirs et sa culture sont passés afin de défaire les détachements historiques et sociaux. Dans cet article, je présente une histoire sur l'émergence de la danse afro-brésilienne et les figures qui sont à l'origine de cet avènement. L'espace sotéropolitan comme un lieu de déploiement des branches du coffre est devenu un lieu de référence pour les recherches axées sur la danse afro, principalement inspirées par la danse desOrixás.

Mots-clés: danse afro-brésilienne; histoire; enseignement.

\section{EL TRONCO HISTÓRICO DE LA DANZA AFROBRASILEÑA}

\footnotetext{
${ }^{1}$ Mestra em dança, professora e pesquisadora da Escola de Dança da Universidade Federal da Bahia, atuando na área de conhecimento referente aos Estudos do Corpo com ênfase em Danças Populares, Indígenas e Afro-Brasileiras. E-mail: marilza.oliveira@ufba.br
} 
Resumen: El histórico de la danza negra en Brasil, específicamente en la ciudad de Salvador, está marcado por la resistencia de sus diseminadores que reconocen en ella el reflejo de la historia y memoria de un pueblo. Aunque vista por muchos como una danza marginal, exótica y anclada en la línea de la invisibilidad, todavía sobrevive. Por lo tanto, resulta relevante abordar pungentes hechos colonizadores por los cuales el negro y su cultura pasaron, a fin de deshacer distanciamientos de orden histórico y social. En este artículo presento un historial sobre el surgimiento de la danza afrobrasileña y las figuras marcadamente responsables de ese advenimiento. El espacio Soteropolitano como el lugar donde las ramas del tronco se desdoblaron, se convirtió en un lugar de referencia para las investigaciones dirigidas a la danza afro, principalmente la inspirada en la danza de los orixás.

Palabras claves: danza afrobrasileña; historia; enseñanza.

\section{INTRODUÇÃO}

Neste estudo, localizo o surgimento da dança afro no Brasil, sua implicação na formação de uma cultura moderna nacional assinalada pelo poder centralizado, autoritário, e forte investimento em temas nacionais que influenciaram as linguagens artísticas. A dança erudita passa a se identificar com o jeito de ser brasileiro utilizando dos repertórios estilizados do bailado popular da cultura indígena e negra, na tentativa de elaborar uma dança brasileira que traduzisse o corpo mestiço. Será apresentado os precursores / construtores dessa história que, para além das suas experiências herdaram e/ou atualizaram a práxis de seus antecessores. Esse assunto será tratado principalmente com referência em Roberto Pereira (2003), Oracy Nogueira (2006), Paulo Melgaço (2007), Mariana Monteiro (2011) e Munanga (2015). Nadir Nóbrega (2006) complementa este referencial.

Para esclarecer sobre o termo "afro", recorro os estudos de Lody (1995) que aponta que essa denominação surge na década de 70 com eficácia semântica e simbólica para designar patrimônio africano no Brasil e, especialmente, identificar nas manifestações consagradamente afro-brasileiras um certo purismo africano.

Segundo Lody (1995) existe uma força revivalista e reafricanizadora que ao longo da história procura resgatar e retomar as tradições genuinamente africanas, que vão tomando corpo nos movimentos políticos de grupos ativamente dispostos a rever conceitos e transformar socialmente visões cristalizadas sobre o negro no Brasil. Nesse contexto uma cultura é valorizada em prol de outra e os conteúdos civilizatórios da diáspora vão aos poucos ganhando referência de defesa cultural da história e dos povos africanos em territórios do pensar, do agir, principalmente na resistência. A construção do rótulo indicativo "afro" trata da revisão histórica, social e política expressa nas 
representações culturais que faz alusão a vida e aos acontecimentos causadores das culturas africanas no Brasil e diferentes processamentos aculturativos e deculturativos.

Categorizo representação como ação nascente sob ótica étnica, cujos movimentos são de etnicidade, de atestações de africanismo sob diferentes nuances e significados etnograficamente identificados e interpretados. Há, sem dúvida, no conceito "afro" um ideal de puro, de pureza africana, de pequenas Áfricas ou de microcosmos africanos imediatamente identificados e relacionados com o continente africano. Fazem parte da construção "afro" as manifestações tradicionais, e nelas há destaque especial para as religiões convencionalmente chamadas de afro-brasileiras - candomblé, xangô, Casa de Mina, batuque, entre outras (Lody, 1995, p.7).

Nos anos de 1920/30, os intelectuais brasileiros trouxeram uma nova forma de pensar a sociedade. A diversidade de culturas e etnias deixaram de ser interpretadas como um problema para a construção de uma unidade nacional. $\mathrm{O}$ objetivo seria o de transformar a massa heterogênea em um povo homogêneo com suas singularidades e uma identidade. A reunião de artistas e intelectuais preocupados com a afirmação da brasilidade, na Semana de Arte Moderna de 1922, foi um dos marcos para essa transformação e previa um projeto de construção de uma identidade nacional com base no amálgama de diferentes culturas.

Nessa perspectiva, o movimento artístico modernista, em uma de suas formas, expressava o nacionalismo brasileiro construído com base na revisão crítica do nosso passado histórico e cultural e na aceitação e valorização das riquezas e contrastes da realidade e da cultura do país. Pela Antropofagia, a exemplo dos rituais antropofágicos, Oswald de Andrade propõe a devoração simbólica da cultura do colonizador europeu, sem com isso perder a identidade cultural. Temas como a desigualdade social, os resquícios da escravidão, o coronelismo, a vida cruel dos retirantes e outros conteúdos sociopolíticos foram retratados nesse período.

O movimento modernista nacional que surgiu como propulsor para a inovação no campo da arte, da cultura, e que englobou as manifestações populares indígenas e africanas na formação de uma cultura moderna brasileira, favoreceu que essas manifestações fossem integradas ao projeto de um estado nacional. Pesquisas voltadas para a criação de modos de dança que se adequassem ao cenário artístico-cultural vigente promoveu o aparecimento da dança afro, conforme atesta Monteiro:

[...] novas modalidades de dança afro fazem sua aparição no cenário cultural brasileiro. Na revista, na chanchada, nos palcos modernistas a referência à cultura popular e dentro dela às tradições afro, é cada vez mais intensa. Torna-

Revista da ABPN • v. 11, n. $27 \cdot$ nov 2018 - fev 2019, p.64-85 
se importante estabelecer sistemas de tradução e releitura daquelas práticas populares, presentes em terreiros, festas populares religiosas e profanas, de forma a alimentar uma temática tipicamente brasileira na produção artística (Monteiro, 2011, p.4 e 5).

Segundo o autor, a dança afro se contextualizou fora dos rituais religiosos, das festas populares e se conectou com a produção radiofônica, com o teatro musical, o cinema, entrecruzando cultura popular, erudita e de massa.

\section{PRECURSORAS DA DANÇA AFRO-BRASILEIRA}

Eros Volúsia e Mercedes Baptista são referências ao se tratar de dança afrobrasileira. Isso porque, na estilização das suas danças, ambas trouxeram a figura do orixá como um dos principais elementos que constituíram as suas pesquisas.

Em 1927 é criada a primeira escola de dança oficial do país, nomeada de Escola de Danças Clássicas do Theatro Municipal do Rio de Janeiro, pela bailarina e coreógrafa russa, Maria Olenewa e o crítico teatral Mário Nunes. No ano seguinte, Eros Volúsia, futura personalidade da dança brasileira, inicia com quatorze anos seus estudos de balé nessa escola, despontando posteriormente como referência nacional da dança por propor a união do balé clássico aos ritmos brasileiros.

Era missão do balé, identificado como arte erudita, transportar com seu requinte as danças populares para serem apresentadas em palcos considerados nobres, como o do Theatro Municipal. Como Eros tinha uma formação clássica, era branca, pesquisava as danças populares oriundas da cultura indígena, negra e também europeia, tinha muita criatividade, seu balé brasileiro rapidamente se tornou notoriedade. Para Pereira (2003, p. 195, “É no batuque, na interpretação dos passos e mímicas do antigo maxixe ou do frevo e maracatus pernambucanos, nas movimentações místicas das macumbas ${ }^{2}$ cariocas que a artista se torna positivamente de maior interesse e verdadeiro espírito criador".

A dança de Eros, apesar da influência das danças de elite, também teve a interferência de artistas mulatas brasileiras como Otília Amorim e Júlia Martins que se apresentavam no teatro de revista interpretando ritmos como o maxixe e o lundu; e da dançarina negra americana, Josephine Backer, que atuou na Companhia Negra de

\footnotetext{
${ }^{2}$ Instrumento musical de origem africana parecido com o reco-reco e usado na umbanda durante as giras. Com o passar do tempo, tudo que envolvia algo fora dos moldes dos ensinamentos impostos pelo catolicismo, protestantismo e outras religiões, era considerado macumba. Com isso, acabou virando um termo pejorativo.
} 
Revistas, criada pelo artista baiano, João Cândido Ferreira. Ele, quando da sua estadia em Paris para fazer apresentações em espetáculos, foi apelidado, pela cor da sua pele de: "Du Chocolat". Em seu retorno ao Brasil, resolveu criar uma versão inspirada na Revue Nègre, espetáculo que envolvia artistas afro-americanos, alcançando o gosto do público parisiense por traduzir nos palcos performances que estilizavam uma África primitiva e exótica. No Brasil, esse gênero teatral musicado não usava a arte negra apenas para se auto-afirmar, mas para fazer críticas a uma sociedade racista e conservadora.

No seu artigo, "Dança Afro: uma dança moderna brasileira", Mariana Monteiro (2011) esclarece que, com o crescimento e estabelecimento da indústria cultural de massa no país, aparecem no cenário cultural, novas modalidades de dança afro. Fora das festas populares e dos rituais religiosos, surge como uma dança de palco, conectada com a produção radiofônica, com o teatro musical, com o cinema, entrecruzando cultura popular, erudita e de massa. Para fomentar uma temática exclusivamente brasileira na produção artística, torna-se necessário instituir sistemas de tradução e releitura das práticas populares presentes em festas populares, religiosas e profanas e terreiros. A autora acrescenta que "A aparição da dança afro, inventada e praticada sob a liderança da artista negra Mercedes Baptista, na década de 50, parece decorrer desse processo" (Monteiro, 2011, p. 5).

Investindo no fomento à valorização da arte brasileira, no ano de 1939 o ministro Gustavo Capanema convidou Eros Volúsia para assumir a direção do curso de ballet do Serviço Nacional do Teatro (SNT), órgão público criado em 21 de dezembro de 1937, subordinado ao Ministério da Educação e de Saúde Pública para incentivar e difundir a cultura nacional. Em 1945, Mercedes Baptista é aceita no curso dirigido por Eros Volúsia e com ela tem suas primeiras aulas de balé clássico e dança folclórica. Para Monteiro (2011), apesar da dança de Eros ser extremamente inovadora e singular, acabou não se consolidando como uma prática diferenciada, pois não foi capaz de conceber, um método, uma pedagogia que desse conta da novidade que propunha.

As danças pesquisadas por Eros eram provenientes das etnias que formaram o nosso povo através da reelaboração das tradições. Uma das suas mais conhecidas coreografias, "Macumba", foi criada a partir das memórias de suas escapadelas quando criança para um terreiro de umbanda que ficava próximo à sua casa. Mesmo não fazendo parte da religião, ela queria reviver no seu corpo através do som dos atabaques a experiência da infância que tornou a se repetir em outros momentos da sua vida. 
Importante registrar a presença de Felícitas Barreto, alemã de nascença, chegou ao Brasil no final da Primeira Guerra Mundial e fixou residência no bairro de Niterói, juntamente com sua família. Felícitas foi contemporânea de Eros Volúsia. Se formou na Escola de Belas Artes como pintora, estudou na Escola de Bailados e também se apresentou no teatro de revistas. Era bailarina, coreógrafa, pintora e escritora.

Ao contrário de Eros, encantou-se pela cultura indígena, viajando e pesquisando por diversos países da América do Sul diferentes aldeias. Os registros dessas experiências foram publicados em livros, um deles, Danças do Brasil: indígenas e folclóricas (s/d). Nesse livro uma parte da pesquisa foi dedicada às danças indígenas e a outra, às danças relacionadas, principalmente, a cultura africana.

Felícitas encarou e viveu a dança de forma vigorosa e, apesar do seu interesse pela cultura indígena ter sido evidente, a cultura negra também lhe causou curiosidade e admiração. Assim como Eros, desde a infância se sentiu atraída pelas manifestações religiosas do candomblé, aprofundando nesse espaço, os seus estudos. Em 1946 criou o Ballet Folclórico Nacional, um dos primeiros do país. A elaboração das coreografias se baseou nas suas pesquisas e, ao seu olhar, as danças afrodescendentes, mesmo se caracterizando como primitivas, sensuais, exóticas, lascivas ou ardentes lhe fascinaram, agradaram.

Em 1946 cria seu Ballet Folclórico Nacional, apresentando-se no dia 23 de outubro no Teatro João Caetano com as seguintes coreografias: Tabu, Macumba, Raio de Lua, Casamento de Zumbi, Feitiço e Yemanjá. Nesta última chocou o público dançando rodeada por negros, nua da cintura para cima, chegando até a ter problemas com a censura (Pereira, 2003, p. 175).

É de fundamental importância observar que tanto Eros, quanto Felícitas, artistas brancas, mesmo se utilizando da riqueza da cultura negra para viabilizar as suas danças, se colocaram, nas suas montagens coreográficas, no lugar de superioridade, relegando a figura do negro ao lugar de subordinação. Essa condição era claramente notada nos diversos espaços onde apresentavam seus trabalhos. Certamente, a valorização a ser dada aos dançarinos e dançarinas afrodescendentes só seria efetivada quando um deles, em busca de sua autonomia e direitos, de forma política, organizada e crítica, ocupasse o espaço de liderança.

Apesar de Eros e Felícitas se interessarem pelos elementos da cultura africana na construção da sua arte, foi Mercedes Baptista considerada a criadora da identidade negra para a dança reconhecida como afro-brasileira. 
Mercedes Baptista nasceu em Campos dos Goytacazes/RJ e jovem se mudou para o Rio de Janeiro. Na sua trajetória exerceu várias atividades profissionais, dentre elas; o trabalho como bilheteira de um cinema, que, quando tinha oportunidade, aproveitava para assistir os filmes. Nessa época já sonhava em brilhar nos palcos e quando soube que poderia ser Girl nos teatros de revista, pensou na possibilidade de se tornar dançarina, alimentando então, o desejo de frequentar uma escola de dança.

Estudar gratuitamente com Eros Volúsia, artista famosa da época, foi algo que marcou a vida de Mercedes. Pouco tempo depois de ter iniciado as aulas ela já subia ao palco para se apresentar, descobrindo ali, sua aptidão para a dança.

No livro, "Mercedes Baptista - A criação da identidade negra na dança", o autor Paulo Melgaço, confirma:

\begin{abstract}
Naquele mesmo ano, aconteceu sua primeira apresentação pública, em um espetáculo organizado por Eros, no Teatro Ginásio Português. O pianista da escola criou a música "pintando o sete" para que ela se apresentasse em conjunto com Otacílio Rodrigues. A apresentação foi um sucesso, confirmando o talento da jovem para a dança (Melgaço, 2007, p. 14).
\end{abstract}

Naquela ocasião, mesmo fazendo papel de empregada no número apresentado, Mercedes Baptista arrancou aplausos da plateia, sendo mencionada no jornal O Globo como "a revelação da noite", juntamente com Otacílio. Esse evento rendeu o convite para que a apresentação fosse feita em outro local e Eros foi solicitada a selecionar os melhores números. Para surpresa de Mercedes, o seu não foi escolhido, ficando magoada por sua professora e coreógrafa ter escolhido outro, interpretado por um bailarino branco e que não tinha nenhum destaque no corpo de baile. Esse foi um dos tantos episódios que ocorreram, fazendo com que Mercedes Baptista se sentisse pouco valorizada e até discriminada por Eros. Até nas coreografias que tratavam de temas da cultura negra, a participação do negro se restringia a tocar atabaques ou fazer papel de serviçal. Nos diversos ambientes culturais frequentados pela elite, as apresentações artísticas que traziam temas relacionados à africanidade eram muito requisitadas e apreciadas; o problema é que era negado ao corpo negro a oportunidade de ocupar esse espaço, estando sabotada, recorrentemente, sua atuação.

Da escola do SNT, Mercedes Baptista reclama por ter sofrido discriminação da parte de Eros Volúsia e de ter sido pouco valorizada. Analisando as fotos em que Eros aparece acompanhada de suas alunas ou de algum corpo de baile,

Revista da ABPN • v. 11, n. $27 \cdot$ nov 2018 - fev 2019, p.64-85 
podemos notar a ausência de bailarinas negras, mesmo quando se tratava de coreografias inspiradas na cultura afro-brasileira. Em geral, vemos apenas a presença de negros em meio aos tocadores de atabaque, no conjunto musical que acompanhava as bailarinas. Talvez isso possa ser considerado um sinal de que, embora o interesse pela cultura de origem africana fosse crescente nos círculos culturais mais elitizados, um espaço real para a atuação do bailarino negro ainda não se efetivara (Monteiro, 2011, p. 6).

Diante dessa situação e também pela ausência de Eros, que viajava muito e não dispunha de tempo necessário para acompanhar os alunos, Mercedes Baptista partiu em busca de outra escola onde pudesse dedicar a sua formação profissional e que lhe oportunizasse desenvolver suas habilidades artísticas. Foi no Theatro Municipal do Rio de Janeiro, depois de uma cordial conversa com Yuco Lindberg, professor responsável pela Escola de Dança dessa instituição, que foi orientada a estudar gratuitamente na turma particular pela tarde e por conta da sua idade e dos sonhos relacionados à dança, foi autorizada a fazer aulas com os alunos do Curso da Prefeitura no turno da manhã. Diante da sua dedicação e talento, Yuco Lindberg começou a incentivá-la e, acompanhando sua dificuldade financeira, conseguiu uma vaga para que trabalhasse no Cassino Atlântico.

Em 1948 aconteceu o concurso público para o ingresso de estudantes do curso de danças no Corpo de Baile do Theatro Municipal e, apesar de Mercedes, com todo talento e técnica achar que tinha pouca chance de ser escolhida para fazer parte do elenco por conta da cor da sua pele, e depois de ser submetida a realizar o teste um mês após a prova das bailarinas, com os concorrentes masculinos, pois não foi avisada da última etapa da seleção, surpreendeu a banca com a facilidade com que executou os saltos, conseguindo sua aprovação.

Foi a primeira vez que o Corpo de Baile do Theatro Municipal admitia negros no seu elenco. Porque, além de Mercedes, o bailarino Raul Soares também foi selecionado. Acredita-se ter sido uma forma de oportunizar alunos da escola da prefeitura, que tinham uma realidade distinta daqueles que faziam aulas particulares, a concorrerem a uma vaga no Corpo de Baile. Mercedes Baptista foi contratada, mas sua arte pouco aproveitada. Percebia-se excluída das coreografias e nas raras vezes que aparecia em cena, era no fundo do palco, se deslocando de um lado a outro.

Nesse período ela também participou do concurso promovido pelo Teatro Experimental dos Negros (TEN) sendo eleita a "Rainha das Mulatas". Segundo Melgaço (2007), o objetivo desse concurso era ampliar a autoestima da mulher negra 
brasileira promovendo sua beleza. Nesse momento se inicia a relação de amizade entre Mercedes Baptista e Abdias do Nascimento, fundador do TEN, que a convida a integrar como bailarina, coreógrafa e colaboradora, a entidade. Começa então sua luta pela imposição do negro como bailarino profissional. Começa o seu trabalho de valorização da dança afro-brasileira.

O Teatro Experimental do Negro fundado em 13 de outubro de 1944 se firmou no ano seguinte a partir dar reuniões promovidas por diversos grupos para propor caminhos pensando na valorização e reconhecimento da identidade social e cultural do brasileiro. Era meta do TEN combater o racismo através do movimento de educação, arte e cultura que promovesse publicamente os valores dos afro-descendentes. As ações articuladas conseguiram capturar o apoio de artistas e intelectuais, formando e colocado no mercado diversos artistas negros. Dentre eles, Mercedes Baptista que, a partir dessa iniciativa, começou a conquistar espaços para sua atuação como bailarina, professora e coreógrafa.

O $1^{\circ}$ Congresso do Negro Brasileiro, elaborado pelo TEN, aconteceu do dia 26 de agosto a 4 de setembro no Rio de Janeiro e tinha como foco discussões e estudos das questões referentes ao negro. As atividades oferecidas tinham o intuito de garantir a troca de conhecimentos entre a cultura negra brasileira e americana. Esse encontro contou com a presença de profissionais e pesquisadores de diversas áreas, dentre estes, Katherine Dunham, antropóloga, dançarina, coreógrafa, professora e ativista social na defesa de causas relacionadas ao negro, que realizou palestra, ministrou aula, apresentou espetáculo com os dançarinos negros da sua companhia e interagiu com outros grupos e trabalhos apresentados. Em seguida, Dunham foi convocada a ministrar aulas para bailarinos com o propósito de oferecer uma bolsa de estudos oportunizando a atuação em seu grupo, na cidade de Nova Iorque, para aquele que apresentasse suas habilidades artísticas criativamente, e Mercedes, envolvida com o movimento negro brasileiro, foi escolhida. Ela viajou depois da licença concedida pelo prefeito Mendes de Morais, após carta redigida pelo amigo Abdias do Nascimento pedindo a sua liberação do Theatro Municipal, já que por ser negra, não era incluída nas coreografias. No seu Brasil muito mais para garantir uma aposentadoria e rever os familiares, que dar continuidade as atividades no Theatro Municipal onde seu trabalho não era reconhecido, pois não havia espaço para desenvolver nenhum trabalho com foco no balé clássico, começou a trazer 
para sua prática o aprendizado adquirido com Dunham, buscando descobrir um estilo que contemplasse a sua afro-descendência.

Foi através do baiano Joãozinho da Goméia, responsável pela popularização da religião do candomblé no Brasil e apresentação dos orixás em espaços públicos, tornando os palcos cariocas a extensão do seu terreiro que Mercedes, mesmo não sendo praticante da religião, se aproximou desse universo vislumbrando a possibilidade de estilizar a dança dos orixás.

Desenvolvendo a sua pesquisa, conheceu os rituais do candomblé ouvindo o ritmo e o movimento das divindades africanas que, combinados aos conhecimentos da dança moderna, adquiridos na sua trajetória, fizeram surgir a dança que ela denominou de afro-brasileira.

Mercedes Baptista propôs uma leitura peculiar, da cultura afro-brasileira e situou a dança afro em novas bases. Mais uma vez o termo se redefiniu. A dança afro de Mercedes Baptista configurou-se como uma prática, um estilo, um repertório de passos e danças em ruptura com o balé clássico e completamente identificado com os novos parâmetros da dança moderna, mas tendo como referência a tradição africana tal qual se configurava no Brasil. O material trabalhado Mercedes Baptista diferia daquele trabalhado por Dunham, já que as danças praticadas no Brasil, não condiziam exatamente com a tradição afro-caribenha (Monteiro, 2011, p.10).

Para colocar em prática a concepção dessa dança, reuniu negros de diferentes atuações profissionais e na Gafieira Estudantina Musical, ponto de convivência e da prática do samba de gafieira, conseguiu uma sala onde podia ministrar suas aulas e divulgar seu trabalho. Com essas pessoas, colocou em prática suas experiências, ministrando aulas de balé clássico, moderno e afro. Nelas viu a possibilidade de dar vida ao sonho de ver nascer um grupo de bailarinos. Durante o ano de 1952, o grupo participou de alguns shows, e as pessoas começaram a apreciar o seu trabalho que aos poucos foi se aprimorando. O elenco foi ficando mais confiante do seu potencial artístico.

Aos poucos esse grupo foi se aprimorando e não demorou muito para que algumas apresentações surgissem e Mercedes Baptista vislumbrasse a possibilidade de criar sua companhia. "Assim nasceu, em 1953, o Balé Folclórico Mercedes Baptista, uma companhia formada exclusivamente por artistas negros e mestiços, com o claro objetivo de criar novos rumos para a dança no Brasil” (Melgaço, 2007, p). Essa iniciativa se deu depois que reuniu alguns dos alunos mais talentosos com os quais desenvolvia seu 
trabalho de dança. Com determinação, Mercedes Baptista e seu grupo folclórico mostraram a força e a beleza das danças afro-brasileiras, atestando a importância da cultura negra no nosso país.

As aulas de Mercedes Baptista eram estruturadas nos moldes do balé clássico e da dança moderna; com barra, centro e diagonal. A expressão corporal se configurava de forma singular, se tornando relevante para o aperfeiçoamento dos dançarinos. Essa investida foi importante num momento crítico da dança no Brasil, por se inserir no movimento modernista como dança elaborada a partir da cultura brasileira, de forma autêntica. Mesmo reconhecendo em Eros a primeira a dar os primeiros passos nessa direção, foi Mercedes Baptista que fez com que a dança moderna brasileira agregasse um repertório específico a uma técnica e um método de ensino. A partir dela, novos caminhos foram abertos para que a dança que hoje nomeamos de afro-brasileira, fosse difundida.

Enquanto propositora da dança afro-brasileira, Mercedes Baptista nos deixou como herança os códigos elaborados a partir da sua pesquisa voltada para a dança dos orixás, articulada com os conhecimentos previamente adquiridos de outras técnicas de dança, como o balé clássico e a dança moderna, organizando um modo de ensino comprometido com a afirmação política de uma dança negra, conferindo uma identidade singular a essa arte.

A crença na força da cultura afrodescendente fez com que se tornasse expoente para que muitos dos seus adeptos dessem continuidade ao seu fazer artístico, disseminando o seu estilo. O seu exemplo de luta, resistência, talento e determinação contra uma sociedade racista e excludente, lhe rendeu, por meio da dança, o reconhecimento pelo seu trabalho, se tornando modelo para que outros profissionais engajados com as questões referentes à cultura negra, no âmbito da dança afro, propagassem os seus ensinamentos.

\section{O TRONCO E SUAS RAMIFICAÇÕES NA CIDADE DE SALVADOR}

Sabemos que no estado da Bahia, especificamente na cidade de Salvador a presença e influência dos africanos foram fundamentais para o desenvolvimento da cultura, da arte e da religião do candomblé, principalmente no que diz respeito à dança e a música. As ramificações decorrentes das pesquisas direcionadas à cultura africana e suas tradições, principalmente pelo viés da dança dos orixás reelaboradas por Mercedes 
Baptista e seus seguidores, para as montagens coreográficas e método de ensino, aportaram na cidade de Salvador, no estado da Bahia, inspirando artistas profissionais e amadores.

Aqui, no início dos anos sessenta, precisamente em 1962, surge, por iniciativa da aluna de Hildegardes Vianna ${ }^{3}$, Emília Biancardi - etnomusicóloga, pesquisadora da música folclórica, professora e especialista nas manifestações tradicionais da Bahia criou o primeiro grupo folclórico do estado, o "Viva Bahia".

O grupo se dedicava à pesquisa e laboratório experimental das manifestações populares afro-baianas, seu repertório musical e danças agregava, segundo Hildegardes Vianna, "legítimos portadores de folclore", aqueles que detinham um determinado saber sobre certa manifestação folclórica. A compreensão de Biancardi (2006) referente ao folclore, incorpora as particularidades dos saberes tradicionais dos povos indígenas, africanos e ibéricos reconhecendo nas trocas culturais inegáveis contribuições que enriquecem os costumes tradicionais baianos voltados, principalmente, para a música e a dança, influenciando, nessa relação híbrida, as construções artísticas. Cabe sinalizar que o trabalho desenvolvido pelo grupo Viva Bahia contemplava as manifestações afrobrasileiras, incluindo a tradição religiosa do candomblé com a reinterpretação da dança dos orixás.

O Grupo Folclórico Viva Bahia viajou por diversos países do mundo realizando apresentações em teatros e participando de festivais. Serviu de inspiração e incentivo para a formação de outros grupos no país e exterior. Foi também um dos grandes colaboradores para a internacionalização da capoeira e teve no elenco mestres reconhecidos na arte e malícia do jogo como Alabama, Jelon Vieira, Amém Santos e Edvaldo Carneiro da Silva, batizado na capoeira como Camisa Roxa, um dos idealizadores do Grupo Folclórico Olodum.

O grupo surgiu em meados dos anos sessenta com participantes de uma comunidade de estudantes universitários que se reuniram para treinar e aprender cânticos de capoeira. Partiram depois para a pesquisa em outras expressões populares como o maculelê e o samba de roda, incluindo também, a dança dos orixás, para fazer exibições em escolas e clubes. Em seguida o grupo transforma em espetáculo todo

\footnotetext{
${ }^{3}$ Hildegardes Cantolino Vianna nasceu em Salvador a 31 de março de 1919, é conhecida no eixo nordestino como folclorista, por ter dedicado toda a vida intelectual, assim como seu pai, aos estudos sobre a chamada cultura popular da Bahia, chegando a se tornar membro da Academia de Letras da Bahia.
} 
aprendizado adquirido se destacando na cena artística local, fazendo sucesso com suas apresentações até no exterior.

Por conta de divergências internas, o Olodum passa a chamar-se Olodumaré, despontando com as coreografias criadas pelo cuiabano Domingos Campos, que muito jovem partiu para o Rio de Janeiro para tentar a carreira de dançarino. Trabalhou no teatro de revista e integrou A Brasiliana, grupo folclórico que fez muito sucesso dentro e fora do país e onde Mercedes Baptista também atuou como coreógrafa. Domingos Campos veio morar em Salvador depois de um convite feito por alguns mestres de capoeira que o viu se apresentar em um espetáculo no Rio de Janeiro dançando Xangô. A finalidade era que ele viesse coreografar o Olodumaré e reproduzisse os padrões dos shows folclóricos da época, onde as danças promovidas pelos afrodescendentes predominavam. Em 1972, o grupo folclórico mais uma vez muda o nome, absorve novos artistas, passando a se chamar, Brasil Tropical (Ferraz, 2012).

Foi nos anos 70 que em Salvador os movimentos negros, caracterizados pela ampla movimentação política e intelectual, realizados por pessoas ou entidades que lutavam contra o racismo e o preconceito, se inspiraram em Abdias do Nascimento, o porta-voz do mundo afro-brasileiro, para propor a construção de uma democracia verdadeiramente plurirracial e pluriétnica. Munanga (2015) comenta que, prefaciando o livro do defensor da cultura negra, Abdias do Nascimento, O genocídio do negro brasileiro, o professor Florestan Fernandes reconhece ter sido a primeira vez que surgiu a ideia de que o Brasil deveria se estabelecer como uma sociedade plurirracial, se tornando democrática para todas as raças e conferindo igualdade econômica, social, e cultural. Neste livro, os negros e pardos da população brasileira são considerados como estoques africanos, detentores de tradições culturais e um destino histórico peculiares.

Com relação as tradições, reconheceram na dança afro um instrumento de transformação social e política, potencializadora das ações ligadas ao movimentos negro. Por intermédio desses movimentos, os blocos afros surgiram e colocaram na prática os conhecimentos referentes a história dos afrodescendentes por meio da expressão da música, do canto e da dança, saindo nas ruas de Salvador representando a cultura africana. Essa investida consentiu às populações negras a afirmação da sua descendência, legitimando uma atitude política contra o racismo. A dança afro, nessa perspectiva, se fortaleceu e ganhou novos rumos. 
Rumos esses que levaram dançarinos oriundos dos grupos folclóricos dessa geração e que apresentavam interesse pela dança dos orixás e sua pesquisa, a trilhar outros caminhos na busca de uma identidade que não ferisse os princípios da religião do candomblé. Bem como artistas da dança que vieram de outros lugares e se identificaram com essa prática realizando pesquisas nesse âmbito.

A Escola de Dança da Universidade Federal da Bahia, fundada no ano de 1956, foi a primeira escola de dança da América Latina e teve como primeira diretora Yanka Rudkka, católica polonesa que estudou com Harald Kreutzberg (1902-1968), aluno de Mary Wigman (1886-1973) foi trazida ao Brasil por Pietro Maria Bardi, que a convidou para fundar o Conjunto de Dança Expressiva do Museu de Arte Contemporânea de São Paulo. Dois anos depois, pisou pela primeira vez em Salvador, enviada pelos Diários Associados de Assis Chateaubriand ${ }^{4}$, para fazer "pesquisa folclórica". Sua Aproximação com a cultura afro consolidou-se depois de aceitar o convite para dirigir a Escola de Dança da UFBA (1956-1959), e pode ser conferida nos títulos de coreografias como “Águas de Oxalá" e "Candomblé” (Risério, 1995).

No mesmo ano de fundação da Escola de Dança da Universidade Federal da Bahia, Lia Robatto, diretora, coreógrafa, dançarina e professora, natural de São Paulo, mudou-se para Salvador a convite da sua mestra Yanka Rudzka, para trabalhar como sua assistente e continuar sua pesquisa em dança e montagens coreográficas A ideia era que ficasse inicialmente por um período de três meses, mas acabou se estabelecendo na cidade. Integrou o Grupo de Dança Contemporânea da Universidade e em 1958 tornouse professora da referida escola. Lia Robatto foi a responsável pela criação da Escola de Dança da Fundação Cultural do Estado da Bahia no ano de 1983.

Ela conta que mesmo polonesa e católica, Yanka se interessou esteticamente pelo candomblé, que conheceu graças a Mário Cravo e Caribé, artistas plásticos de prestígio na Bahia. De seu apartamento no bairro do Chame-Chame conseguia captar os ritmos emitidos pelo do som dos atabaques, vindos provavelmente do candomblé da proximidade. Yanka Rudzka se sentiu atraída por esse universo que incorporou em suas criações, antes, unicamente europeias, elementos da dança dos orixás, sem cair na mera

\footnotetext{
${ }^{4}$ Os Diários Associados, de propriedade de Assis Chateaubriand (1892-1968), que foi jornalista, empresário, político e escritor, tinham como missão contribuir para a construção de uma sociedade justa e democrática com a produção e distribuição de informação e entretenimento de qualidade. Busca, ainda, promover o desenvolvimento, apoiar a livre iniciativa, estimular a educação, debater os grandes temas nacionais e preservar os valores regionais.
} 
transposição dos movimentos. Para Lia Robatto, Yanka Rudzka não tinha interesse nem envolvimento religioso com o candomblé, mas com a linguagem, o campo de formas e o gestual.

Aos olhos de Robatto, Yanka Rudzka foi considerada inovadora por ter conseguido captar os valores da cultura negra, traduzindo criativamente as coreografias inspiradas no candomblé, se distanciando da narração descritiva da dança dos orixás sem descaracterizar o tema e com inventividade coreográfica contemporânea.

Nesse fluxo, chega ao Brasil, em 1971, com 31 anos, Clyde Morgan, norteamericano da cidade de Cincinnati que com 18 anos começou a fazer aulas do método Royal Ballet e dança afro no Karamu Hause, centro comunitário que tinha como missão passar para os membros da comunidade negra as várias culturas africanas. $\mathrm{Na}$ sua dissertação de mestrado sobre a presença de Clyde Morgan na Escola de Dança da UFBA, com título, "Agô Alafiju Odara”, Nádir Nóbrega, pesquisadora, professora, dançarina e coreógrafa das danças de matriz africana e que também foi aluna de Morgan e mestre King relata que aos 23 anos teve o primeiro contato com a dança moderna se dedicando ao estudo da técnica até conhecer, na década de 1960, José Limón ${ }^{5}$, que o convidou para dançar na sua companhia como solista. Morgan atuou como coreógrafo em várias universidades americanas e na Broadway. Trabalhou com o percussionista e coreógrafo nigeriano, Michael Babatunde Olatungi reconhecendo que seus conhecimentos por danças africanas se ampliaram no Drum Dance Group, dirigido pelo referido percussionista.

Essa experiência despertou em Clyde Morgan o desejo em pesquisar as danças africanas nos países de origem. Assim, ele fez intercâmbio com diversas entidades africanas aprofundando a sua pesquisa. No ano que chegou ao Brasil, foi apresentado à vida cultural do Rio de Janeiro por Arminda Villa Lobos. Conheceu o corpo de baile do Teatro Municipal, o carnaval carioca, e foi levado por Mercedes Baptista para conhecer a religião afro-brasileira. Foi na casa do babalorixá Miguel Grosso, filho de Yemanjá e do Tião, antigo componente do grupo de Camisa Roxa e Domingos Campos, que também tinha ligação com o terreiro de Joãozinho da Goméia que teve seu primeiro contato com o candomblé. Nesse mesmo período, Ana Lúcia Oliveira, professora baiana, ao ter conhecimento do trabalho de Morgan, contactou a Escola de Dança da

\footnotetext{
5 Coreógrafo mexicano, naturalizado norte-americano, foi um dos expoentes da Dança moderna Americana nos anos de 1950.
} 
UFBA que o convidou para ministrar um curso de extensão de dança africana e da técnica de dança moderna de José Limón. Já na escola, em reconhecimento ao seu trabalho, em 1972 é contratado como professor e coreógrafo do Grupo de Dança Contemporânea - GDC. “[...] embora sua motivação de vir à Bahia tenha sido justamente a de aprender capoeira e conhecer a cultura afro-brasileira” (Nóbrega, 2006, p.45)

Nóbrega nos conta que o GDC foi o espaço onde o norte-americano pode colocar em prática os aprendizados artísticos dos Estados Unidos e da África. No período que dirigiu o grupo promoveu a junção da música percussiva dos atabaques do candomblé, efeitos sonoros e flauta transversal. Sob a sua direção o GDC apresentou coreografias inspiradas na cultura popular, especialmente de matriz negra.

Nóbrega (2006) nos informa que para Morgan:

[...] as possíveis buscas pelo sagrado encontram um porto seguro em Salvador, no Terreiro, Ilê Axé Opô Afonjá, espaço tradicional afro-brasileiro do sistema religioso iorubá. Ele se confirma na religião candomblé como ogã na casa acima citada [...] (Nóbrega, 2006, p.43).

A relação de Morgan com a religião do candomblé influenciou nas suas concepções artísticas o motivando a incluir nas suas obras temas voltados à mitologia dos orixás. Clyde Morgan foi um dos responsáveis pela divulgação das danças africanas no Brasil e suas conexões com a dança moderna e afro-religiosa

Em meio a esse processo de buscas e descobertas, de uma dança negra que ressignificasse a dança das divindades, um destaque especial para Mestre King, por ter conseguido, com a sua pesquisa baseada na dança dos orixás, despontar no cenário da dança baiana como professor referência no ensino da dança afro.

Raimundo Bispo dos Santos - com quem fiz uma entrevista para obtenção dos dados aqui relatados - conhecido como Mestre King, integrou o Grupo Folclórico Viva Bahia, onde foi apresentado ao candomblé pela etnomusicóloga Emília Biancardi e também pelo Olodumaré, onde vivenciou processos de aprendizagens que muito contribuíram para sua formação antes de entrar na universidade.

Segundo informações concedidas por Raimundo Bispo para esta pesquisa, ele nasceu em 1943, no município de Santa Inês, situado no estado da Bahia. Veio para Salvador com sete anos de idade para ser criado por uma família de árabes, servindo, quando rapaz, à Marinha. Estudou no Colégio Estadual Central e após ser expulso, foi 
cantar no Coral do Mosteiro de São Bento. Conheceu a capoeira por meio de um amigo e foi batizado na roda, pela atitude de liderança que exercia sobre seus colegas como "King".

No ano de 1972, ingressou no curso de Licenciatura em Dança da Universidade Federal da Bahia, sendo o primeiro homem negro a integrar o corpo discente. Em 1977, criou o grupo de dança Gênese e, em 1988, especializou-se em Coreografia na mesma Escola. Foi na faculdade que seu interesse em estudar a dança dos orixás se aprofundou lhe motivando a frequentar por mais de um ano diferentes terreiros de candomblé. Chegou a ser chamado de "fura-roncó", por invadir os segredos da religião com seus constantes questionamentos, inclusive, sendo rotulado como " o macumbeiro" na Escola de Dança da UFBA, por conta do compromisso com a sua pesquisa.

Cabe destacar quando a polonesa Yanka Rudzka veio morar em Salvador para assumir a gestão da Escola de Dança da UFBA e acabou se interessando pela religião do candomblé, em um período onde essa prática e assunto eram considerados tabus por parte do pensamento conservador e preconceituoso da sociedade da época, não chegou a ser apontada como macumbeira, como foi posteriormente mestre King, ao ser criticado por seus colegas por frequentar, como pesquisador, terreiros de candomblé. O mesmo aconteceu com Clyde Morgan por também ter se inspirado nos orixás para compor algumas de suas coreografias, não sendo criticado nem mesmo quando se converteu à religião do candomblé.

A partir da situação apresentada, considero duas possibilidades que podem explicar o tipo de assédio sofrido por mestre King. A primeira trata da valorização e respeito creditados aos profissionais que vinham de fora e se autorizavam, de alguma forma, a utilizarem nas suas concepções artísticas elementos da religião do candomblé e não sofriam nenhum tipo de represália; como se tudo que viesse de fora fosse "melhor" das que aqui já estavam e "em favor de imigrantes estrangeiros que recebiam privilégios especiais" (Torres, apud Munanga, 2015, p. 59). A segunda se refere ao fato de Mestre King reproduzir a dança dos orixás em sala de aula e em montagem coreográficas, levando àquelas pessoas que carregavam preconceito e repúdio pela religião a agirem intolerantemente diante dessa investida, como complementa Santos ao refletir sobre a Bahia: “[...] essa sociedade discriminadora é marcadamente negra em termos culturais. Vive, consome e tem internalizados em sua cultura valores negros" (Santos, 2003. P. 
149). Entretanto, não era capaz de reconhecê-los também na religiosidade afrobrasileira.

A situação ganha diferente configuração quando determinado grupo artístico, com integrantes negros se desloca para divulgar a dança afro-brasileira em outro estado ou país. A recepção dada ao seu trabalho artístico é diferente. Uma admiração exacerbada em torno do que consideram exótico, sensual e até primitivo. Os produtores artísticos desses denominados "shows folclóricos" inspirados na cultura afrodescendente local e até nacional, de grande visibilidade, se alimentam da cultura negra através de atividades turísticas exportando a cultura de forma distorcida, vendendo uma imagem estereotipada do negro brasileiro, negociando valores financeiros que não são repassados de forma justa aos artistas.

Essa realidade é verificada pelos constantes comentários por parte de alunos e colegas de profissão que muitas vezes se submetem a esse tipo de situação devido às poucas oportunidades oferecidas pelo mercado para expressarem a sua arte.

Mestre King, quando aluno da Escola de Dança da UFBA, integrou o Grupo de Dança Contemporânea, estudando com Clyde Morgan. Também nessa instituição atuou como professor substituto no período de 1992 a 1994, retornando ao âmbito acadêmico para compartilhar com os discentes seus conhecimentos acerca da dança afro.

Assim como Mercedes Baptista, Mestre King não era candomblecista, mas via nessa manifestação afro-religiosa a possibilidade de reinterpretação e estilização da dança dos orixás. Seu objetivo era, a partir dessas pesquisas, ministrar aulas de dança. Aproveitou os conhecimentos trazidos das suas experiências como dançarino do Grupo Folclórico Viva Bahia e o Olodumaré, unindo a dança dos orixás aos movimentos da capoeira, do maculelê e do samba e da dança moderna.

No início da sua carreira como professor e coreógrafo, King foi acusado de ter desrespeitado a dança dos orixás por reproduzi-la na sala de aula. Ele reconhece que fez muita coisa errada, como cantar e ensinar as cantigas de fundamento, as danças e ritmos característicos de determinada divindade. Explica que hoje respeita mais o candomblé e declara "que não faz a dança do orixá, imita as movimentações que pra ele representam algo de belo e precioso".

Na Bahia, Mestre King é considerado o precursor da dança afro, sendo o responsável por disseminar nas comunidades da periferia de Salvador e escolas públicas, mesmo antes de entrar na Escola de Dança da UFBA, a cultura 
afrodescendente por meio da dança afro. Sua atuação como professor se inicia em 1969, quando foi chamado para dar aulas no Serviço Social do Comércio - SESC por seis meses e acabou sendo contratado pela entidade.

Nesse espaço consolidou seu trabalho como especialista no ensino da dança afrobrasileira, sendo responsável pela formação de diversos dançarinos e professores que são referência, principalmente, de dança afro, no Brasil e exterior. Cito alguns: Zebrinha, Armando Pekeno, Tânia Bispo, Raimunda Sena, Rosângela Silvestre, Elísio Pita, Augusto Omolu (in memorian), Edileusa Santos, Rita Rodrigues, Leda Ornelas, José Ricardo, Nildinha Fonseca, Julieta Rodrigues, Carlos Neguinho, Amélia Conrado, Ricardo Biriba. E outros, como a pesquisadora Inaicyra Falcão e Suzana Martins, que com ele tiveram a oportunidade de dividir o palco e são referência nas suas respectivas pesquisas com temática negra.

Os profissionais acima mencionados, como prolongamento desses ramos, cada um, na singularidade do seu fazer e pensar a dança afro-brasileira é responsável por manter viva a tradição do povo negro na reelaboração de suas danças. Essa relação histórica, referenciada no legado de Mercedes Baptista e Mestre King, se aplica principalmente, ao ensino. Incluo-me (Marilza Oliveira da Silva), além de Amilton Lino, Roquidélia Santos, Pakito Lázaro, Denilson José, Tatiana Campêlo e Vânia Oliveira como ramificação desse processo de disseminação da dança afro que se apresenta como símbolo de resistência contra uma sociedade racista, preconceituosa e excludente. Representamos os mais novos ramos desse tronco histórico que permanece pela resiliência e espírito de luta dos nossos antecessores.

\section{CONSIDERAÇÔES}

Apesar de cada professor obedecer a lógica das suas experiências e pesquisas na organização das suas didáticas, é preciso reconhecer que prevalece, em grande escala, pode-se afirmar, até hoje, o formato de ensino elaborado por Mercedes Baptista e atualizado por Mestre King. A estrutura da aula se dá pela mistura de elementos da cultura popular afrodescendente e a outras técnicas de danças somadas às manifestações afro-religiosas. O que nessa hibridez não fica de fora é o que chamamos de simbologia, transposição, ressignificação, reelaboração, recriação, reinvenção, estilização, da "dança dos orixás". Possível argumentar que "dança afro-brasileira" é considerada aquela que de alguma forma preserva, mantém os estudos de Mercedes Baptista e mestre King. 
Principalmente quando falamos de Salvador, um dos polos de resistência afirmado com os movimentos realizados pelos afrodescendentes que lutaram pelo resgate da cultura de matriz africana e seus valores, que ao longo da história foram violentados, negados, oprimidos. A dança afro-brasileira, nesse sentido, surge como contradispositivo do racismo, da exclusão, da invisibilidade; negadores da identidade negra. Ela é atitude política!

Reconhecer a importância dos profissionais que se dedicaram a sua disseminação pelo caminho da luta e resistência em combate a uma sociedade racista e opressora, é dever de todos. Oportunizar que outros, compromissados com esse fazer, possam reinventar a tradição inserindo no contexto da contemporaneidade outras formas de pensar a ancestralidade traduzindo-a para a vida, para a dança, é missão.

Espero com esse artigo poder contribuir para que a dança afro, como ação política, possa sair da linha da invisibilidade se inserindo em espaços onde a hierarquia e poder operam de forma desigual, convocando aquele que fica do outro do muro a conhecer e valorizar o lado de cá!

\section{REFERÊCIAS}

AGAMBEN, Giorgio. Profanações. São Paulo: Boitempo, 2007. Tradução de:

Selvino José Assmann.

BARCELLOS, Mario Cesar. Os orixás e o segredo da vida: lógica, mitologia e ecologia. Rio de Janeiro: Pallas, 2008.

BAUMAN, Zygmunt. Identidade: entrevista a Benedetto Vecchi. Rio de Janeiro: Jorge Zahar Ed., 2005. Tradução de: Carlos Alberto Medeiros.

BENISTE, José. Mitos Yorubás: o outro lado do conhecimento. Rio de Janeiro: Bertrand Brasil, 2010.

CAMPBELL, Joseph. O poder do mito: entrevista a Bill Moyers. São Paulo: Palas Athena. Tradução de Carlos Felipe Moisés.

CANCLINI, Néstor Garcia. Culturas híbridas. Tradução: Ana Regina Lessa e Heloísa Pezza Cintrão. São Paulo: Editora da USP, 2011.

CHARLOT, Bernard. Da relação com o saber às práticas educativas. São Paulo: Cortez, 2013.

CLYDE, W. Ford. O herói com o rosto africano: mitos da África. São Paulo: Summus, 1999. Tradução de Carlos Mendes Rosa.

CONRADO, Amélia. Capoeira angola e dança afro: contribuições para uma política de educação multicultural na Bahia. Salvador: UFBA, 2006. Tese. Universidade Federal da Bahia. 
DESMOND, Jane. Tradução. Salvador: Revista Dança, 2013. <http://www. portalseer.br/index,php/revista dança/article/ download 7674/6040>. Acesso em: 03 mar. 2015

FALCÃO, Inaicyra. Corpo e ancestralidade: uma proposta pluricultural de dança arteeducação. São Paulo: Terceira Margem, 2006.

FELICITAS. Danças do Brasil. Indígenas e folclóricas. Rio de Janeiro, Tecnoprint, s/d.

FERRAZ, Fernando. $O$ saber fazer das danças afro: Investigando matrizes negras em movimento. São Paulo, UNESP, 2012. Dissertação de Mestrado. Universidade Estadual Paulista.

FREIRE, Paulo. Educação como prática da liberdade. Rio de Janeiro: Paz e Terra, 2011. Terra, 1996.

Pedagogia da autonomia: saberes necessários á prática educativa. São Paulo: Paz e

HALL, Stuart. A identidade cultural na pós-modernidade. Rio de Janeiro: DP\&A,2006. Tradução de: Tomaz Tadeu da Silva e Guacira Lopes Louro.

LAUNAY, Isabelle. A elaboração da memória na dança contemporânea e a arte da citação. Salvador: Revista Dança, 2013. <http://www. portalseer.br/index,php/revista dança/article/ download 7674/6040>. Acesso em: 03 mar. 2015.

LIGIÉRO, Zeca. Corpo a corpo: estudo das performances brasileiras. Rio de janeiro: Garamond, 2011.

LODY, Raul. O povo do santo: religião, história e cultura dos orixás, voduns, inquices e caboclos. Rio de Janeiro: Pallas, 2005.

LODY, Raul e SABINO, Jorge. Danças de Matriz Africana: antropologia do movimento. Rio de Janeiro: Pallas, 2011.

LUZ, Marco Aurélio. Agadá: dinâmica da civilização africano-brasileira. Salvador: EDUFBA, 2000.

LAKOFF, George e JOHNSON, Mark. Metáforas da vida cotidiana. São Paulo:Educ, 2002. Tradução: Mara Sophia Zanotto.

MARTINS, Suzana. A dança de Yemanjá Ogunté: sob a perspectiva estética do corpo.Salvador: EGBA, 2008.

MORIN, Edgar. Os sete saberes necessários à educação do futuro. São Paulo: Cortez, 2002.

MUNANGA, Kabenguele. Rediscutindo a mestiçagem no Brasil - identidade nacional versus identidade negra. Belo Horizonte: Editora Autêntica, 2015.

NÓBREGA, Nadir. Agô alajifu, odara! A presença de Clyde Wesley Morgan na escola de dança da UFBA, 1971-1978. Salvador: UFBA, 2006. Dissertação de Mestrado. Universidade Federal da Bahia. 
PRANDI, Reginaldo. Mitologia dos Orixás. São Paulo: Companhia das Letras, 2001.

SANTOS, Helio. A busca de um caminho para o Brasil: A trilha do círculo vicioso. São Paulo: Editora Senac São Paulo, 2003.

SODRÉ, Muniz. Reinventando a educação: Diversidade, descolonização e redes. Rio de janeiro: Vozes, 2012.

VERGER, Pierre. Orixás. Salvador: Corrupio, 1997. 